\title{
Indicator minerals in kimberlites and their respective stream sediments, Gibeon Kimberlite Province, Namibia
}

\author{
Nguno Muatara Anna-Karren
}

Department of Geology, University of Helsinki, P.O Box 11 (Snellmaninkatu 3) 00014 Helsinki Finland

This study deals with macrocrystic kimberlite indicator minerals from Anis Kubub, Berseba Reserve (Ovas), Diamantkop, Hanaus 2, Mukorob, Lichtenfels, Louwrensia and Achterfontein kimberlite suite from the off-craton Gibeon Kimberlite Province of Southern Namibia. The aim was to study the composition and distribution of kimberlite indicator minerals in the pipes and dykes as well as sediments from streams draining the kimberlite area. Altogether 15 pipes and dykes and 37 stream sediments were sampled. Streams samples were mainly taken from trap sites where maximum amounts of heavy minerals were accumulated and from weathered surfaces of kimberlite pipes and dykes. Indicator minerals were hand-picked from $0.5-1.0 \mathrm{~mm}$ and $1.0-2.0 \mathrm{~mm}$ fractions of the concentrates. The minerals included purple, red, reddish-brown and orange garnets, black ilmenite, pale and emerald green chrome diopside and black chromite. A representative number of each indicator mineral was analyzed by electron microprobe in the EPMA-laboratory of Geological Survey of Finland (GSF).

Ilmenite tends to be the most abundant indicator mineral in the study area but its abundance varies considerably (from $<1 \%$ to $95 \%$, generally $>50 \%$ ). Garnets show a similar variation, with the proportion usually less than $45 \%$. The remainder consists mostly of chrome diopside (generally $<2 \%$, maximum about $30 \%$ ), rare chromite and chrome-spinel.

Compositionally, most of the garnets fall in the garnet lherzolite field, a few plot in the wehlite field and only 9 in the harzburgite+dunite field (Fig. 1). $\mathrm{Cr}_{2} \mathrm{O}_{3}$ contents of the garnet macrocrysts range from $\sim 0 \mathrm{wt} \%$ to $\sim 9 \mathrm{wt} \%$. The ilmenites have a fairly restricted composition with $\mathrm{TiO}_{2} 48 \mathrm{wt} \% \pm 2(1$ s.d.), $\mathrm{MgO}$ between 6.1-15.0 wt $\%$ and $\mathrm{Cr}_{2} \mathrm{O}_{3} 1.62 \mathrm{wt} \%$ (average) \pm 0.03 (1 s.d. ). Cr-diopside has relatively constant $\mathrm{MgO}$ of $\left(16.5 \mathrm{wt} \% \pm 0.4\right.$ (1 s.d.), but $\mathrm{Cr}_{2} \mathrm{O}_{3}$ varies between $0.2-2.5 \mathrm{wt} \%$. The spinel varies in composition from chrome spinel to low-Cr chromite ( average $=42 \mathrm{wt} \% \mathrm{Cr}_{2} \mathrm{O}_{3}$ ).

In terms of relative proportion of garnets, $\mathrm{TiO}_{2}$-poor garnet $\left(<0.45 \mathrm{wt} \% \mathrm{TiO}_{2}\right)$ predominates both in the pipes $(69 \%)$ and in the stream sediments $(82 \%)$. In contrast, titanium-garnet $(0.45$ to $0.87 \mathrm{wt} \%$ $\mathrm{TiO}_{2}$ ) is much lower abundance in the stream sediments and rare further away from the source. High Ti-garnet $\left(>0.87 \mathrm{wt} \% \mathrm{TiO}_{2}\right)$ proportions do not show much variation from pipe to stream sediments (Fig. 2. a,b.).

Heavy mineral studies show that the general trend with increasing distance from the source is a drastic and rapid increase in the proportion of ilmenite. Approximately $5 \mathrm{~km}$ from the source ilmenite proportions both in coarse and fine fractions exceed $80 \%$. Importantly, the original indicator mineral proportions of the pipes do not affect this trend significantly. Considering garnets, low Ti-Cr pyrope is the most resistant. Due to its preferential cleavage, $\mathrm{Cr}$-diopside disintegrates more easily and therefore disappears rapidly from the coarse fraction of stream sediments and may temporarily increase in the fine fraction proximal to the source.

Presence of an additional kimberlite source contributing to a stream sediment can be first detected in an increase in the abundance of garnets in the coarser fraction, and also in the finer fraction. Other facts supporting an additional source include the appearance of less durable garnets and often $\mathrm{Cr}$ - 
diopside, occasional appearance of ilmenites with characteristic surface alteration, garnet with kelyphitic rims and intergrowths of either ilmenite, garnet or $\mathrm{Cr}$-diopside.

Figure 3 shows indicator minerals abundance patterns calculated from samples of Lichtenfels area (east of the Fish River. It can be seen that another source starts to contribute already before $1.3 \mathrm{~km}$ from the known pipe $(0 \mathrm{~km})$. This is confirmed at $2.2 \mathrm{~km}$ distance by a sharp increase in the proportion of garnets. The $4.8 \mathrm{~km}$ site exhibits the normal ilmenite increase without any indication of new sources. The sample from $5.6 \mathrm{~km}$ distance was taken just after the confluence with another stream, here again, contribution from another source is clear. In a successful exploration of diamonds, the understanding of the behaviour of the indicator mineral species during the river transport is vital for the correct interpretation of the calculated abundance patterns derived from stream sediment, especially in the case of complicated drainage pattern and multiple sources.

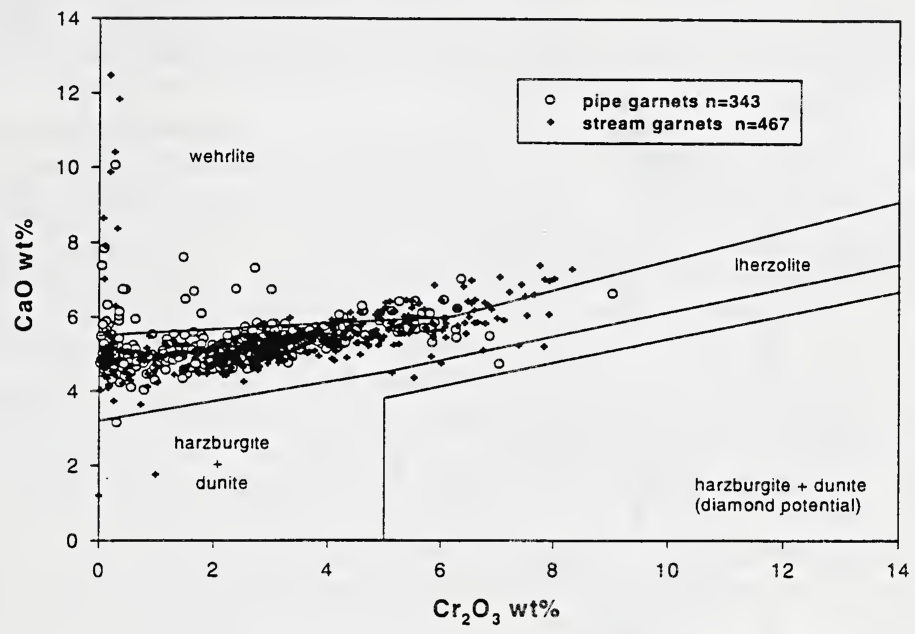

Fig.1. $\mathrm{CaO}$ vs $\mathrm{Cr}_{2} \mathrm{O}_{3}$ plot for macrocryst garnets from the off craton Gibeon kimberlites. $(\mathrm{n}=$ number of grains)

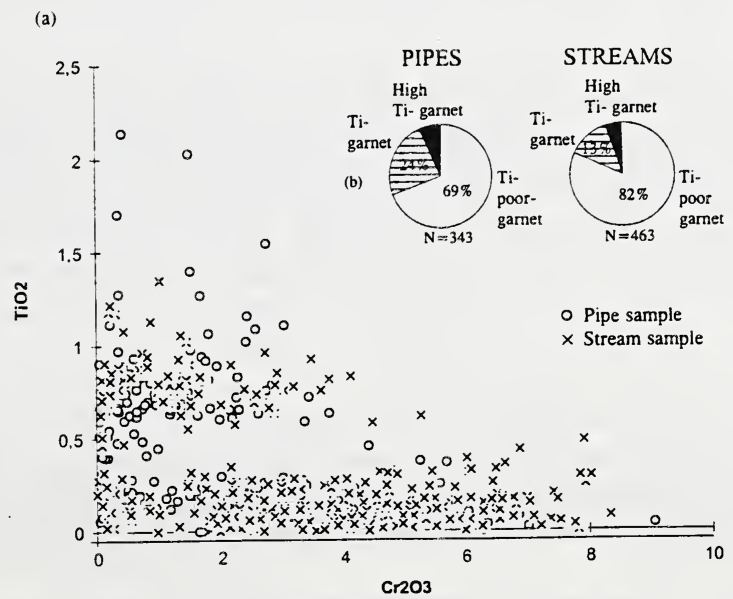

Fig.2.(a) $\mathrm{TiO}_{2}$ vs $\mathrm{Cr}_{2} \mathrm{O}_{3}$ plot (same samples in Fig.1.), (b) diagram showing the proportions of garnet in the pipes and in the stream sediments 


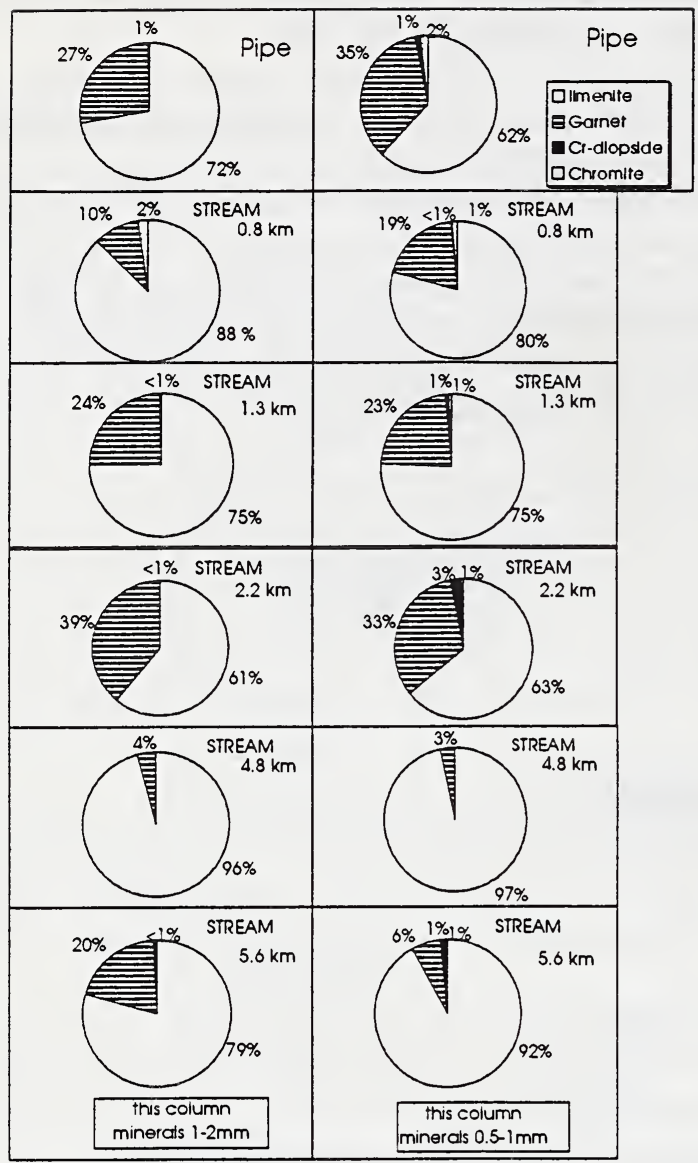

Fig.3. The distribution pattern of indicator minerals in stream sediment and a known kimberlite pipe.

The patterns indicate draining from multiple sources (Lichetenfels, east of the Fish River).

\section{Acknowledgements}

Special thanks go to Tuomo Manninen (The Geological Survey of Finland, Rovaniemi) for assisting during course of sampling of the study material in Namibia. Financial assistance from FINNIDA and logistic support by the Geological Survey of Namibia are gratefully acknowledged. I owe great thanks to Jukka Marmo, Tegist Chernet, Lassi Pakkanen, Hugh O`Brien, Ahti Nissinen, Sirkku Mäenluoma, from the Geological Survey of Finland, Espoo and Tapani Rämö from the University of Helsinki Finland.

\section{References}

Afanas 'ev, V.P., Sobolev, N.V., and Khar 'kiv, A.D., 1984, The Evolution of the chemical composition of pyrope associations in old dispersion halos around kimberlite bodies. Soviet Geology And Geophysics V. 25, p, $130-134$.

Janse, A.J.A. 1975., Kimberlite and related rocks of the Nama Plateau of South West Africa (Namibia): Physics and Chemistry of the Earth V. 9, p. 81-94.

Mitchell, R.H., 1986. Kimberlite : Mineralogy, Geochemistry and Petrology. Plenun Press, New York. Muggeridge, M.T., 1995, Pathfinder sampling techniques for location primary sources of diamond: Recovery of indicator minerals, diamonds and geochemical signatures. In: W.L. Griffin (editor), Diamond Exploration: Into the 21 st Century. Journal of Geochemical Exploration 53, p. 183-204. 